Arq. Bras. Med. Vet. Zootec., v.70, n.1, p.169-173, 2018

\title{
Descriptive analysis of rabies in wild animals in the state of Sergipe, Brazil
}

[Análise descritiva da raiva em animais silvestres no estado de Sergipe, Brasil]

\author{
K.D. Antunes ${ }^{1}$, J.C.C. Matos $^{1}$, L.P. Mol $^{1}$, M.A. Oliveira ${ }^{1}$, T.L.M. Arcebispo ${ }^{1}$, V.G. Santos ${ }^{2}$, \\ T.M. Oliveira ${ }^{1}$, C.C. Fontes ${ }^{3}$, C.H.L. Reis ${ }^{4}$, S.A. Diniz ${ }^{1}$, P.L.L. Pereira ${ }^{1}$, M.X. Silva ${ }^{1}$ \\ ${ }^{1}$ Escola de Veterinária - Universidade Federal de Minas Gerais - Belo Horizonte, MG \\ ${ }^{2}$ Universidade do Estado de Minas Gerais - Belo Horizonte, MG \\ ${ }^{3}$ Empresa de Desenvolvimento Agropecuário de Sergipe - Nossa Senhora do Socorro, SE \\ ${ }^{4}$ Laboratório Central da Fundação de Saúde Parreiras Horta - Aracaju, SE
}

\begin{abstract}
The wild cycle of rabies constitutes a serious challenge to epidemiological surveillance for disease control in domestic, companion or production animals, and in humans. The understanding of rabies virus circulation in the natural environment is increasingly important due to the constancy of natural reservoirs of the disease and the presence of potential vectors of the infection to humans and domestic animals. Aiming to evaluate the occurrence of rabies in the State of Sergipe a total of 935 hematophagous bats (Desmodus rotundus), 46 wild dogs (Cerdocyon thous) and 24 primates (Callithrix spp.) were analyzed from 1987 to 2014, of which 1 bat, 17 crab-eating foxes and no primates were positive. Due to the lack of positive results in hematophagous bats, the main vector of herbivorous rabies, more studies are needed to monitor cases, because from an epidemiological point of view, Sergipe is endemic for herbivorous rabies. Epidemiological surveillance of rabies virus in wild animals is primordial for the success of disease control programs in herds of domestic animals and humans.
\end{abstract}

Keywords: bats, crab-eating foxes, hydrophobia, primates

\section{RESUMO}

O ciclo silvestre da raiva constitui um sério desafio para a vigilância epidemiológica no controle da doença nos animais domésticos, de companhia ou de produção, e nos seres humanos. O entendimento sobre a circulação do vírus rábico no ambiente natural é cada vez mais importante, em razão da constância de reservatórios naturais da doença e da presença de vetores potenciais da infecção aos humanos e aos animais domésticos. Com o objetivo de avaliar a ocorrência da raiva no estado de Sergipe, foram analisados 935 morcegos hematófagos (Desmodus rotundus), 46 cachorros-do-mato (Cerdocyon thous) e 24 primatas (Callithrix spp.) no período de 1987 a 2014, dos quais resultaram positivos um morcego, 17 cachorros-domato e nenhum primata. Em que pese a contundente falta de resultados positivos em morcegos hematófagos, principal vetor da raiva dos herbívoros, mais estudos são necessários no monitoramento dos casos, pois o estado, do ponto de vista epidemiológico, é endêmico para a raiva dos herbívoros. A vigilância epidemiológica do vírus da raiva nos animais silvestres é primordial para o sucesso dos programas de controle da doença em rebanhos de animais domésticos e em seres humanos.

Palavras-chave: morcegos, cachorros-do-mato, hidrofobia, primatas

\section{INTRODUCTION}

Rabies is an enzootic disease in developing countries (Expert..., 2004). The most important reservoirs, also responsible for the transmission of human rabies in Latin America are the dog and some wild animals such as foxes and bats. In

Recebido em 4 de novembro de 2016

Aceito em 2 de abril de 2017

E-mail:kda_vet@hotmail.com
Brazil, while the number of cases in dogs is declining, the wild cycle continues to be important (Silva et al., 2009) in the distribution of rabies in the country.

The wild cycle of rabies in Brazil has been maintained active mainly by several species of chiroptera, wild canids and small primates 
(Aguiar et al., 2011). Desmodus rotundus, a hematophagous bat, is the main wild species transmitting herbivorous rabies, although approximately 40 species of bats are considered reservoirs of the infection. Among the species of wild canids of the Brazilian fauna, the crabeating fox (Cerdocyon thous) and the field fox (Lycalopex vetulus) were identified as the main reservoirs and transmitters of rabies in the country (Carnieli et al., 2006; Araújo et al., 2014).

Wild canids corresponded to $88 \%$ of rabies cases reported in the Northeast from 2002 to 2009 , proving the strong relationship of wild canids and the wild cycle of rabies in this region (Wada et al., 2011). It is worth noting that in the Northeast it is common to breed foxes and other wild animals as pets, although this practice is considered a crime under Law No. 5,197, dated January 3, 1967 (Silva et al., 2009). The close relationship between men and wild animals increases the risk of transmission of rabies to humans and domestic animals (Araújo et al., 2014).

One way of prevention would be the application of vaccines to wild carnivores, just as it was done in the urban cycle in domestic animals. The use of baits containing attenuated virus-derived vaccines for the control of rabies in red foxes has been demonstrated in the United States and Canada, and this form of vaccination has been efficiently employed in the oral immunization of foxes in Europe (Blancou and Meslin, 1996). Oral immunization campaigns allowed the elimination of rabies in red foxes in several countries of the European continent (Slate et al., 2009; Araujo, 2012). In Brazil, foxes (Cerdocyon thous) play a much more important role in maintaining and disseminating rabies than previously thought, and have a significant public health implication, since in this region the monitoring of these animals is often inefficient or absent, and the practice of vaccination of wild animals has not been used in the country (Araújo et al., 2014).

The increasing importance of the wild cycle, involving bats and terrestrial mammals, demonstrates the importance of rabies virus epidemiology study in these species, in order to determine the best strategies for prophylaxis and control of the disease (Araujo, 2012).
Therefore, the objective of this work is to describe and evaluate the occurrence of rabies in wild animals such as crab-eating fox (Cerdocyon thous), hematophagous bats (Desmodus rotundus) and primates (Callithrix spp.) according to the diagnoses carried out in the State of Sergipe. In addition to identifying the respective variables of the disease, in order to build a universal perspective of the moment of rabies in the wild cycle in the State of Sergipe.

\section{MATERIAL AND METHODS}

The present study was carried out based on epidemiological information about rabies in the entire state of Sergipe, located in the Northeast region of Brazil, which occupies an area of $21,918.493 \mathrm{~km}^{2}$, corresponding to $0.26 \%$ of the national territory, and has 75 municipalities. The State represents, in macroregional terms (Pecuária..., 2014), 4\% of the cattle herd of the Northeast, $5 \%$ of equines, $2 \%$ of sheep, etc.

The results of the rabies diagnoses carried out on wild animal species from throughout the State during the period 1987 to 2014 were used as the source of information. Diagnoses were made based on reports of suspected rabies cases examined at the Central Laboratory - LACEN, from the Parreiras Horta Health Foundation of the State of Sergipe, through the use of direct immunofluorescence techniques (DIT) and intracerebral inoculation in mice (ICIM).

For the description and analysis of the spatial distribution of wild animals, according to the positive and negative results, the EpiInfo 7.2 Program was used. A descriptive epidemiological study, as a function of the spatio-temporal distribution was carried out in order to identify the trend occurrence of positive results.

\section{RESULT}

A total of 1,005 diagnostic results were observed in wild species from 1987 to 2014, as follows: 935 in hematophagous bats of the genus Desmodus rotundus, 46 in crab-eating fox of the genus Cerdocyon thous, and 24 examinations in primates of the Genus Callithrix spp. Among the 935 results obtained in hematophagous bats, 926 were considered negative, two cases were discarded for failing to complete the forms, five 
ignored, one case inconclusive and only one positive for rabies. Among the crab-eating foxes, 27 were negative for rabies, 17 were positive, and two were inconclusive. Twenty negative results were observed in the primates, and the remaining four were not submitted to diagnosis due to deficiency in filling out the forms. The results are shown in Table 1 and Figure 1.

Table 1. Rabies cases in wild animals occurred in the State of Sergipe, Brazil, for periods of time, from 1987 to 2014

\begin{tabular}{c|c|c|c|c|c|c|c|c|c}
\hline \multirow{2}{*}{ Period } & \multicolumn{4}{|c|}{ Bats } & \multicolumn{3}{c|}{ Crab-eating-foxes } & \multicolumn{3}{c}{ Primates } \\
\cline { 2 - 11 } & Pos. & Neg. & Inc. & Pos. & Neg. & Inc. & Pos. & Neg. & Inc. \\
\hline Before 1990 & 0 & 19 & 0 & 2 & 2 & 0 & 0 & 4 & 0 \\
\hline 1990 to 1994 & 0 & 14 & 0 & 1 & 1 & 0 & 0 & 1 & 0 \\
\hline 1995 to 1999 & 0 & 1 & 0 & 3 & 1 & 0 & 0 & 2 & 0 \\
\hline 2000 to 2004 & 1 & 53 & 1 & 5 & 3 & 0 & 0 & 2 & 0 \\
\hline 2005 to 2009 & 0 & 512 & 0 & 5 & 7 & 2 & 0 & 7 & 0 \\
\hline 2010 to 2014 & 0 & 327 & 0 & 1 & 13 & 0 & 0 & 4 & 0 \\
\hline
\end{tabular}

Note: Pos.= Positive; Neg.= Negative; Inc.= Inconclusive.

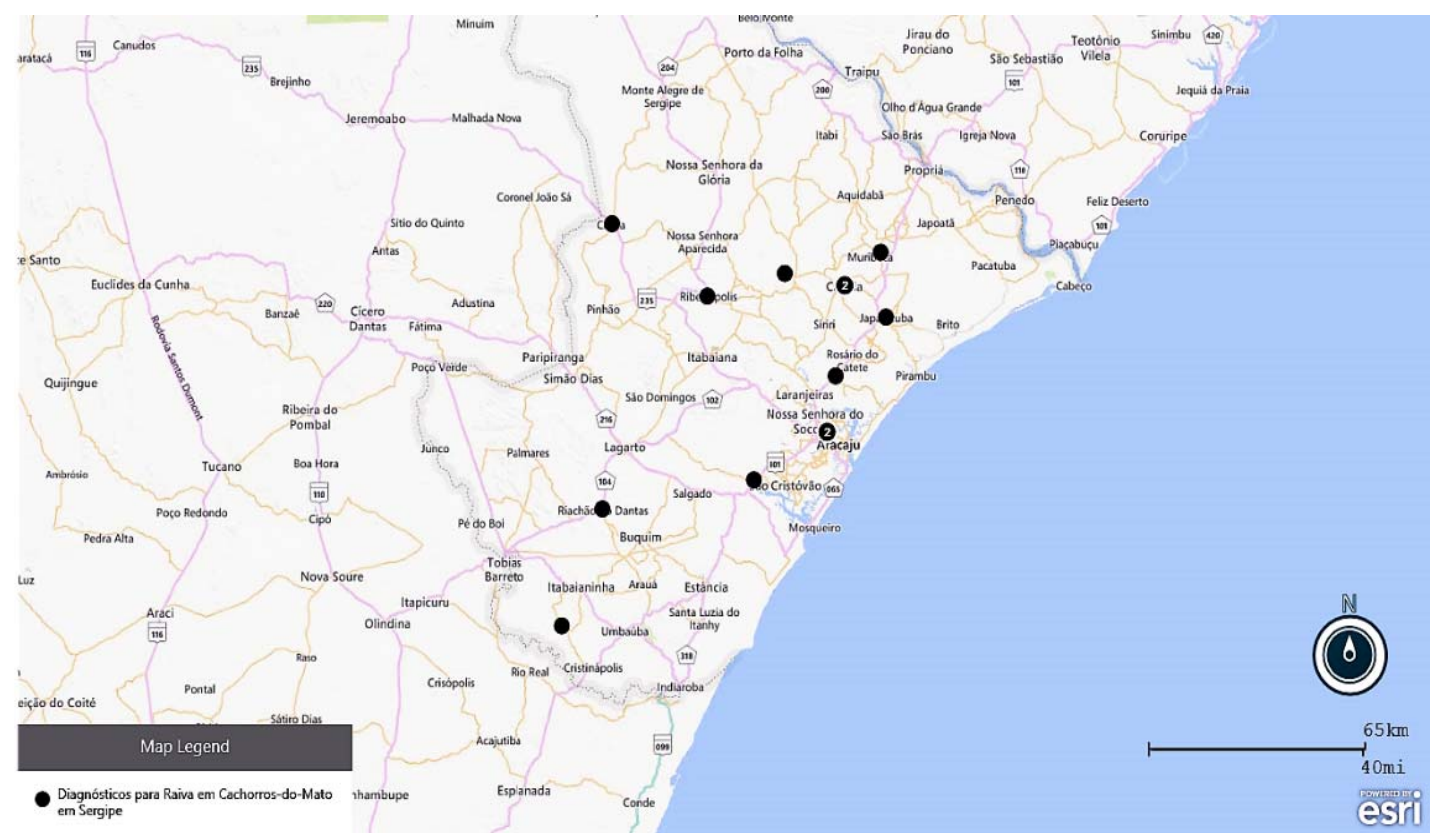

Figure 1. Distribution of positive diagnoses for rabies in crab-eating foxes in the state of Sergipe, Brazil, between 1987 and 2014.

\section{DISCUSSION}

The rabies virus has been identified in 41 different species of bats in Brazil, comprising 25 genres and three families - Phyllosomity (43.9\%), Vespertilonidae (29.3\%) and Molossidae (26.8\%). Among these species, three are hematophagous, Desmodus rotundus, Diphylla ecaudata and Diaemus youngii and the others mainly comprise insectivorous and frugivorous bats (Sodré et al., 2010). The participation of chiroptera, therefore, in the epidemiology of the disease is unquestionable and requires an important epidemiological surveillance attention on these species, both in animal health and public health, due to the constant presence of these animals in urban environments. The almost total absence of positive results for rabies among the hematophagous bats observed in the present study is at least incomprehensible. Considering the adequacy of the techniques and their respective applications, a more significant number of positive results were expected, given the volume of animals analyzed (935 specimens) and the time period of observation (27 years). Also noteworthy is the lack of positive results 
among the primates, although the low frequency of tests on materials from these animals observed during the study period.

Although the official absence of human or animal rabies suspected or effectively transmitted by non-human primates in the State of Sergipe is largely attributed to Callithrix spp. A certain implication in the transmission of rabies in Northeast Brazil. In fact, in recent years, this species has represented an emerging importance in relation to wild rabies in the state of Ceará (Souza et al., 2013).

Even with the legal prohibition for maintaining wild animals in captivity, in Ceará, located in the Northeast of Brazil, it is common to find these animals being raised in several properties as pets, domiciled or semi-domiciled, which may increase the risk of transmitting rabies to humans and other animals (Souza et al., 2013).

Only during the period from 2000 to 2012 in Ceará, four human cases of rabies transmitted by these small primates occurred and according to the Central Laboratory of Ceará - LACEN, 65 positive marmosets were diagnosed in the state, in 2012 (Souza et al. 2013).

Also in Ceará, from 2001 to 2011, 620 cases of rabies were registered in animals, of which $45.96 \%$ were canines, followed by $18.54 \%$ in foxes and $16.77 \%$ in cattle, according to the Health Department of the State of Ceará and in the last five years, a greater number of wild animals positive for rabies $(78-53.42 \%)$ were observed when compared to canine and feline cases together (25 - 17.2\%). Among 78 positive wild animals, 19 (24.3\%) were marmosets (Souza et al., 2013).

Although the groups of animals studied in the two states in Northeastern Brazil are not fully comparable due to the variability of species, a discrepancy in the distribution of rabies among groups of animals can be observed when $37 \%$ of rabies positive samples are seen in crab-eating foxes in Sergipe from 1987 to 2014, while in Ceará only $18.54 \%$ of rabies positive samples in foxes from 2001 to 2011. But the studied period in both states shows that there was much more annual collection of samples for study in Ceará than in Sergipe. At this moment, the possible errors in data entry can lead us to discuss the performance of surveillance specifically in the State of Sergipe that may be providing incomplete data or possible underreporting.

Vaccination of wild animals is not carried out in Brazil, but rather, passive surveillance through viral identification in animals found dead in several situations, especially on roads and highways, as well as surveillance and management of wild animals' actions (Wada et al., 2011).

Post-mortem viral detection in animals suspected of exposing humans and domestic animals to the risk of contracting the disease allows the application of post-exposure prophylactic measures, preventing the fatal progression of infection and the use of unnecessary sanitary measures in negative cases (Trimarchi and Nadin -Davis, 2007; Araujo, 2012).

The terrestrial wild cycle of rabies is represented in Brazil mainly by marmosets (Callithrix spp.) and crab-eating foxes (Cerdocyon thous). According to the Health Surveillance Secretariat of the Brazilian Ministry of Health data, in 2007, wild canids were responsible for $7.9 \%$ of the 165 human deaths from the disease in the country in the period 1986-2006 (Kotait et al., 2007). In the Northeast region, two wild canids have been reported as reservoirs of the rabies virus: $C$. thous (crab-eating fox) and Pseudalopex vetulus (gray fox) (Gomes, 2004; Caniele et al., 2008).

Rabies is an endemic disease in Brazil. Regardless of the epidemiological cycle of transmission, it requires a constant and efficient epidemiological surveillance, due to the great impact that it produces on animal health, economic damages and public health (Oliveira et al., 2013), resulting in loss of human lives and costs of numerous post-exposure interventions, clinically and epidemiologically justified, or not.

\section{CONCLUSIONS}

The results observed in this study show the circulation of the virus in wild environment in Sergipe with a permanently open window, able to feed the disease in urban and rural environments. This situation imposes the need for a permanent and systematic epidemiological surveillance of rabies in natural environments, in key wild species such as bats, carnivores and 
primates, since the country has no wild species vaccination program. The visibility of rabies impact on public health and livestock, should attract quite easily the disease control programs. Nevertheless, the terrestrial wild cycle, perhaps due to its complexity, has obtained little or no attention from the research and the sanitary authorities in the country, besides an incipient epidemiological surveillance. Efforts should be directed to new researches and epidemiological surveillance of the disease in natural environment in order to effectively control the disease in the State.

\section{REFERENCES}

AGUIAR, T.D.F.; COSTA, E.C.; ROLIM, B.N. et al. Risco de transmissão do vírus da raiva oriundo de sagui (Callithrix jacchus), domiciliado e semidomiciliado, para o homem na região metropolitana de Fortaleza, Estado do Ceará. Rev. Soc. Bras Med. Trop., v.44, p.356-363, 2011.

ARAUJO, D.B. Estudo epidemiológico do vírus da raiva em mamíferos silvestres provenientes de área de soltura no litoral Norte do Estado de São Paulo, Brasil. 2012. 104f. Tese (Doutorado em Biotecnologia) - Instituto de Ciências Biomédicas, Universidade de São Paulo, São Paulo, SP.

ARAÚJO, J.L.; DANTAS, A.F.M.; GALIZA, G.J.N. et al. Aspectos histopatológicos e imunohistoquímicos da raiva em raposas Cerdocyon thous. Acta Sci. Vet., v.42, p.67, 2014.

BLANCOU, J.; MESLIN, F.X. Modified live-virus rabies vaccines for oral immunization of carnivores. In: MESLIN, F.X.; KAPLAN, M.M.; KOPROWSKI, H (Ed.). Laboratory techniques in rabies. 4ed. Genebra: WHO, 1996. p.324-331.

CARNIELI JR., P.; BRANDÃO, P.E.; CARRIERI, M.L. et al. Molecular epidemiology of rabies virus strains isolated from wild canids in Northeastern Brazil. Virus Res., v.120, p.113-120, 2006.

CARNIELI JR., P.; FAHL, W.O.; CASTILHO, J.G. et al. Characterization of rabies virus isolated from canids and identification of the main wild canid host in Northeastern Brazil. Virus Res., v.131, p.33-46, 2008.

EXPERT consultation on rabies. Geneva: WHO, 2004. 121p.
GOMES, A.A.B. Epidemiologia da raiva: caracterização de vírus isolados de animais domésticos e silvestres do semi-árido paraibano da região de Patos, Nordeste do Brasil. 2004. 107f. Tese (Doutorado em Medicina Veterinária) Programa de Pós-graduação em Epidemiologia Experimental Aplicada às Zoonoses, Universidade de São Paulo, São Paulo.

KOTAIT, I.; CARRIERI, M.L.; CARNIELI JR., P. et al. Reservatórios silvestres do vírus da raiva: um desafio para saúde pública. Bol. Epidemiol. Paul., v.4, p.2-8, 2007.

OLIVEIRA, M.S.; FROTA, F.P.; CARVALHO, M.P. et al. Frequência da raiva em herbívoros e humanos no estado do Tocantins de 1999 a 2010: relatório técnico. Acta Vet. Bras., v.7, p.180-183, 2013.

PECUÁRIA de Sergipe. [Rio de Janeiro]: IBGE, 2014. Disponível em: $<$ http://www.ibge.gov.br/estadosat/temas.php?sig $\mathrm{la}=$ se\&tema=pecuaria $2014>$. Acessado em: 22 jul. 2016 .

SILVA, M.L.C.R.; LIMA, F.S.; GOMES, A.A.B. et al. Isolation of rabies virus from the parotid salivary glands of foxes (Pseudalopex vetulus) from Paraíba State, Northeastern Brazil. Braz. J. Microbiol., v.40, p.446-449, 2009.

SLATE, D.; ALGEO, T.P.; NELSON, K.M. et al. Oral rabies vaccination in North America: opportunities, complexities and challenges. PLoS Neglect. Trop. Dis., v.3, p.1-9, 2009.

SODRÉ, M.M.; GAMA, A.R.; ALMEIDA, M.F. Updated list of bat species positive for rabies in Brazil. Rev. Inst. Med. Trop. São Paulo, v.52, p.7581, 2010.

SOUSA, M.S.; RIBEIRO, W.L.C.; DUARTE, N.F.H. et al. Transmissão da raiva por Sagui (Callithrix jacchus) no Estado do Ceará, Brasil. Uma revisão. Rev. Bras. Hig. Sanit. Anim., v.7, p.270-287, 2013.

TRIMARCHI, C.V.; NANDIN-DAVIS, S.A. Diagnostic evaluation. In: JACKSON, A.C.; WUNNER, W.H. (Ed.). Rabies. 2.ed. Londres: Elsevier, 2007. p.411-469.

WADA, M.Y.; ROCHA, S.M.; MAIAELKHOURY, A.N.S. Situação da raiva no Brasil, 2000 a 2009. Epidemiol. Serv. Saúde, v.20, p.509518,2011 